\title{
Meta-analysis of the effect of white clover inclusion in perennial ryegrass swards on milk production
}

\author{
M. Dineen, ${ }^{\star} †$ L. Delaby, $\ddagger$ T. Gilliland, $† \S$ and B. McCarthy*1 \\ ${ }^{*}$ Teagasc, Animal and Grassland Research and Innovation Centre, Moorepark, Fermoy, Co. Cork, Ireland \\ †Institute of Global Food Security, Queens University Belfast, Belfast, Ireland \\ fINRA, AgroCampus Ouest, UMR 1348, Physiologie, Environnement et Génétique pour l'Animal et les Systèmes d'Elevage, \\ F-35590 Saint-Gilles, France \\ §Agri-Food Biosciences Institute, Plant Testing Station, Crossnacreevy, Belfast, BT5 7QJ, United Kingdom
}

\begin{abstract}
There is increased demand for dairy products worldwide, which is coupled with the realization that consumers want dairy products that are produced in a sustainable and environmentally benign manner. Forage legumes, and white clover (Trifolium repens L.; WC) in particular, have the potential to positively influence the sustainability of pasture-based ruminant production systems. Therefore, there is increased interest in the use of forage legumes because they offer opportunities for sustainable pasture-based production systems. A meta-analysis was undertaken to quantify the milk production response associated with the introduction of WC into perennial ryegrass swards and to investigate the optimal $\mathrm{WC}$ content of dairy pastures to increase milk production. Two separate databases were created. In the grass-WC database, papers were selected if they compared milk production of lactating dairy cows grazing perennial ryegrass-WC (GC) swards with that of cows grazing perennial ryegrass-only swards (GO). In the WC-only database, papers were selected if they contained milk production from lactating dairy cows grazing on GC swards with varying levels of WC content. Data from both databases were analyzed using mixed models (PROC MIXED) in SAS (SAS Institute, Cary, NC). Within the grass-WC database, where mean sward WC content was $31.6 \%$, mean daily milk and milk solids yield per cow were increased by 1.4 and $0.12 \mathrm{~kg}$, respectively, whereas milk and milk solids yield per hectare were unaffected when cows grazed GC compared with GO swards. Stocking rate and nitrogen fertilizer application were reduced by 0.25 cows/ha and $81 \mathrm{~kg} / \mathrm{ha}$, respectively, on GC swards compared with GO swards. These results highlight the potential of GC production systems to achieve similar levels of production to GO systems but with reduced fertilizer nitrogen
\end{abstract}

Received January 13, 2017.

Accepted October 1, 2017.

${ }^{1}$ Corresponding author: brian.mccarthy@teagasc.ie inputs, which is beneficial from both an economic and environmental point of view. In the context of increased demand for dairy products, there may be potential to increase the productivity of GC systems by increasing fertilizer nitrogen use to increase stocking rate and carrying capacity while also retaining the benefit of $\mathrm{WC}$ inclusion on milk production per cow.

Key words: meta-analysis, white clover, dairy cow, milk production, grazing

\section{INTRODUCTION}

There is increased demand for dairy products worldwide, which is coupled with the realization that consumers want dairy products that are produced in a sustainable and environmentally benign manner (Godfray et al., 2010). As a consequence, European pasturebased livestock production systems have changed considerably over the past 2 decades and will continue to evolve in response to these societal and environmental pressures (Lüscher et al., 2014). Traditionally, white clover (Trifolium repens L.; WC) was included in perennial ryegrass (Lolium perenne L.; PRG) mixtures as a means of improving sward nutritive value and reducing nitrogen $(\mathrm{N})$ fertilizer use. However, cheap N fertilizer, which improves pasture production and simplifies grazing management, has led to a reduction in the use of WC, with declining levels of WC reported in temperate grazing regions such as Western Europe and New Zealand. Forage legumes, and WC in particular, can make an important contribution to the sustainability of pasture-based ruminant production systems (Peyraud et al., 2009). Therefore, there is increased interest in the use of forage legumes because they offer opportunities for sustainable pasture-based production systems by (1) increasing pasture yield, (2) substituting inorganic $\mathrm{N}$ fertilizer inputs with symbiotic $\mathrm{N}_{2}$ fixation, (3) mitigating and facilitating adaptation to climate change, and (4) increasing the nutritive value of pasture and raising the efficiency of conversion of pasture to animal protein (Lüscher et al., 2014; Delaby et al., 2016). 
Previous research has reported conflicting evidence of the effect of pasture WC content on milk production per cow. Harris et al. (1997a) reported that increased pasture WC content results in higher milk yields due to a combination of higher pasture intake and increased nutritive value of the pasture. Recently, Egan et al. (2015) reported annual milk solids (kg of fat + protein; MS) production of $487 \mathrm{~kg} /$ cow from a PRG-WC (GC) sward in comparison with $454 \mathrm{~kg} / \mathrm{cow}$ on a PRG-only (GO) sward. Other previous research has also indicated that including WC in a PRG sward can result in an increase in daily milk production per cow (Riberio-Filho et al., 2003; Cosgrove et al., 2006). However, other experiments report little to no effect of GC swards on milk production when compared with GO swards (Ledgard et al., 1998; Humphreys et al., 2009; Enriquez-Hidalgo et al., 2014). The interpretation of results (e.g., milk yield per cow and per hectare, pasture yield) from experiments involving WC must take into account the underlying management practices associated with WC swards. Stocking rate and N fertilizer application rates, 2 of the most important factors in determining milk production within pasture-based systems (Bryant et al., 1981; Macdonald et al., 2008), often differ between experimental treatments with and without WC, and this has an effect on the results obtained. Riberio-Filho et al. (2003) concluded that the high individual performance of the cows obtained on GC swards was, however, offset by a major reduction in the stocking rate that results from the reduced pasture productivity of GC swards. In accordance with this, Ryan (1989) reported that a GC system had a reduction in carrying capacity in the region of 20 to $25 \%$ compared with that of a PRG N-based system. Ryan (1989) also stated that a GC system produced $84 \%$ of the milk per hectare obtained from an N-based system.

The effect or lack of effect of WC on milk production is possibly attributable to the WC content of the sward. Research undertaken by Lee et al. (2004) reported that with increasing WC proportions in the diet, milk and MS yield increased from 17.6 to $20.4 \mathrm{~kg} /$ cow per day and 1.32 to $1.52 \mathrm{~kg} / \mathrm{cow}$ per day, respectively, as the proportion of WC increased from 0 to $60 \%$. Harris et al. (1997a) reported that 50\% sward WC content was the most realistic option for optimum milk yield as cows grazing such a pasture could be expected to produce $95 \%$ of maximum possible milk yield. However, high sward WC contents (i.e., >50\%) may have implications in terms of animal health because of the increased risk of bloat (Clarke and Reid, 1974) and on the environment because increased $\mathrm{N}$ inputs (regardless of the $\mathrm{N}$ source) lead to increased $\mathrm{N}$ leaching in pasture-based production systems (Ledgard et al., 2009). Therefore, obtaining the optimum sward WC content to increase animal performance without compromising animal health and the environment is an overriding objective.

Results from a single experiment will not provide a definitive understanding of the effect of $\mathrm{WC}$ inclusion on milk production because the conditions under which observations are made in a single experiment are inevitably narrow (Sauvant et al., 2008). A meta-analysis approach (Glass, 1976), summarizing the results across published studies in a particular area and in combination with new statistical techniques, allows increased precision of analysis of effects across multiple experiments (St-Pierre, 2001; Sauvant et al., 2008; Lean et al., 2009). The objective of this study, therefore, was to quantify the milk production response associated with the introduction of WC into PRG swards from the published literature and to find the optimal sward WC content of dairy pastures to increase milk production.

\section{MATERIALS AND METHODS}

\section{Literature Search, Data Criteria, and Database Design}

An electronic literature search [Web of Science (http://thomsonreuters.com/web-of-science/) and Google Scholar (http://scholar.google.com/)] was conducted to identify papers for data extraction in which the effect of WC inclusion on milk production in lactating dairy cows was studied. The search was undertaken using the following key words in different combinations: white clover, milk production, perennial ryegrass, grazing, and dairy cow. More papers were identified by reviewing the reference list in the publications resulting from the search. These papers were also used to study the effect of differing sward WC content on milk production.

Papers were selected if (1) they compared milk production from a GC sward with that from a GO sward, (2) lactating dairy cows were under strip or rotationalgrazing management, and (3) they compared at least 2 WC contents under similar experimental conditions. The inherent management associated with GC swards (i.e., reduced stocking rate and $\mathrm{N}$ fertilizer application rates) made it difficult to locate data, so a decision was made to compare milk production from GO and GC swards under different stocking rate and $\mathrm{N}$ fertilizer regimens with all other experimental conditions the same to have sufficient data. After accounting for publications with duplicate data or insufficient information provided, a starting database was constructed. The database was conceptualized with rows representing treatments within an experiment and columns reporting treatment characteristics and least squares means of measured variables. All papers were 
organized by author name(s), year of publication, and publishing journal. Each comparison of GO versus GC within an experiment was allocated an individual experimental code or study effect to account for the variation between experiments not explained by WC content. Experimental characteristics required included experimental design, number of cows, experimental duration, number of treatments, stocking rate, grazing days per hectare $(\mathbf{G d} / \mathbf{h a})$, lactation length, WC content of the sward, milk production, BW results per cow and per hectare, and sward nutritive value results. In experiments in which a subfactor was studied (e.g., at 2 supplementation levels or at 2 postgrazing sward heights) or multiple years of data were reported, comparisons of milk production from GC and GO swards conducted under similar experimental conditions were considered as independent studies.

\section{Calculations}

Occasionally, measured variables such as solids-corrected milk (SCM) yield per cow or Gd/ha were not reported and were subsequently calculated according to the following formulas:

$$
\begin{gathered}
\text { SCM yield } / \text { cow }=(12.3 \times \text { fat yield }) \\
+[6.56 \times(\text { protein yield }+ \text { lactose yield })] \\
-(0.0752 \times \text { milk yield })
\end{gathered}
$$

$\mathrm{Gd} / \mathrm{ha}=($ no. of cows $\times$ grazing experiment length $) /$ area used during grazing experiment (ha),

Also, within the database, variables were not consistently reported in each experiment. Similar to McCarthy et al. (2011), milk yield per cow per day was reported, and milk yield per hectare was then derived according to the formula

$$
\mathrm{Gd} / \mathrm{ha} \times \text { milk yield/cow per day }=\text { milk yield } / \text { ha. }
$$

\section{Requirements}

For analytical purposes, 2 main subsets of data were created. The grass-WC (GWC) database included experiments that contained a GO treatment that was taken as the base milk production that swards containing WC could be compared with. Grass WC database experiments reflected the milk production effect of introducing WC into a GO sward. The GWC database contained 15 papers and 35 comparisons of milk production from GO and GC swards published between 1985 and 2015. As the objective of the study was to analyze the effect of WC inclusion in a PRG sward, within the database, the GO treatment within each experiment was considered the base level of production, with the milk production at this $\mathrm{WC}$ content (i.e., 0\%) considered as base milk production. By selecting this variable to standardize measurement methods across experiments, it allowed the identification of the true effect of the inclusion of WC from a range of experiments that included large variations in experimental conditions. As all experiments did not contain a GO treatment, treatments that had a sward WC content below $5 \%$ were considered as the GO treatment and were considered the base WC content, and the milk production at this WC content was considered as the base milk production.

The second database, the WC-only (WCO) database, included experiments without a GO treatment, with GWC database GC treatments included. The aim of this database was to predict the resultant milk production effect of varying sward WC content. In the WCO database, papers were selected if they contained milk production from lactating dairy cows grazing on GC swards with varying levels of WC content. The WCO database was constructed similarly to the GWC database. These WCO database experiments reflect the overall effect on milk production as WC content increases in the sward. The WCO database contained 26 papers and 131 data points of milk production from GC swards published between 1989 and 2015. A range of experimental designs was represented in both databases, including completely randomized designs, Latin square designs, randomized block designs, factorial designs, and reduced factorial designs. The majority of the studies included in the database were from New Zealand, Ireland, the United Kingdom, and France.

\section{Statistical Analysis}

Individual variables (e.g., milk yield, MS yield) from the GWC database were analyzed using linear mixed models (PROC MIXED) in SAS (SAS Institute, 2006). Terms included in the model were treatment (GC or GO) and the study effect (individual experimental code), which represented the variance between studies not accounted for by the variables in the model, as described by St-Pierre (2001) and more recently Sauvant et al. (2008). The study effect was included as a random effect, and an unstructured variance-covariance structure among records was used. Significance was declared at $P<0.05$, and tendencies were declared at $0.05<P<0.1$. Publication bias was assessed using funnel plots as described by Lean et al. (2009) and the publication bias test (metabias) using the $\mathrm{R}$ package meta (version 4.0-2; Schwarzer et al., 2015). 
Within the WCO database, per-cow data were analyzed using linear mixed models (PROC MIXED) in SAS (SAS Institute, 2006), with WC content (CC) as a continuous variable included as a fixed effect, the study effect (individual experimental code) included as a random effect, and an unstructured variance-covariance structure among records according to Equation 1:

$$
\mathrm{Ry}=a+\text { study }+b \times \mathrm{CC}+c \times \mathrm{CC}^{2},
$$

where Ry is the predicted production of variable $\mathrm{y}$ in response to $\mathrm{WC}$ content change, $a$ is the intercept, study is the study effect, $b$ represents the linear coefficient, and $c$ represents the quadratic coefficient. Where $c$ was observed to be greater than $P=0.10$, it was removed from the analysis.

Per-hectare data within the WCO database were analyzed similarly (Equation 2). Study was excluded and Gd/ha was included in the model, and only experiments with an experimental length greater than $150 \mathrm{~d}$ were used for the analysis to obtain an interpretative relationship between production per hectare, sward WC content (CC), and $\mathrm{Gd} /$ ha due to the very important role of $\mathrm{Gd} /$ ha in per-hectare performance:

$$
\mathrm{Ry}=a+b \times \mathrm{CC}+c \times \mathrm{CC}^{2}+d \times \mathrm{Gd} / \mathrm{ha},
$$

where Ry is the predicted production of variable $\mathrm{y}$ in response to $\mathrm{WC}$ content change and a $\mathrm{Gd} /$ ha change, $a$ is the intercept, $b$ represents the linear coefficient, $c$ represents the quadratic coefficient, and $d$ represents the coefficient of $\mathrm{Gd} / \mathrm{ha}$.

A further analysis of the WCO database was undertaken to try to investigate the interactions between sward WC content (CC), stocking rate (SR), Gd/ha, and $\mathrm{N}$ fertilizer. Milk and MS yield per cow were analyzed according to Equation 3:

$$
\mathrm{Ry}=a+b \times \mathrm{CC}+c \times(\mathrm{SR} \text { or Gd/ha })+d \times \mathrm{N} \text {, }
$$

where Ry is the predicted variable y in response to $\mathrm{WC}$ content, stocking rate, and $\mathrm{N}$ change; $a$ is the intercept; $b$ represents the linear coefficient for WC content; $c$ represents the coefficient for stocking rate for per-cow variables and the coefficient for $\mathrm{Gd} /$ ha for per-hectare variables; and $d$ represents the coefficient for $\mathrm{N}$ fertilizer application.

\section{RESULTS AND DISCUSSION}

\section{Publication Bias}

Publication bias was assessed using funnel plots and the metabias test in $\mathrm{R}$ ( $\mathrm{R}$ version 4.0-2; Schwarzer et al., 2015). For milk yield per cow, assessment of the funnel plots indicates that there was no publication bias in the data set (Figure 1). The $P$-value for the publication bias test was 0.67 , again indicating no evidence for publication bias.

\section{Effect of WC Inclusion in PRG Swards on Milk Production}

Within the GWC database, the total number of data comparisons for milk production from a GO sward and a GC sward was 35 . The mean experimental characteristics and milk production per cow and per hectare for the GWC database were as follows: number of cows = 44 , stocking rate $=3.45 \mathrm{cows} / \mathrm{ha}$, experiment length

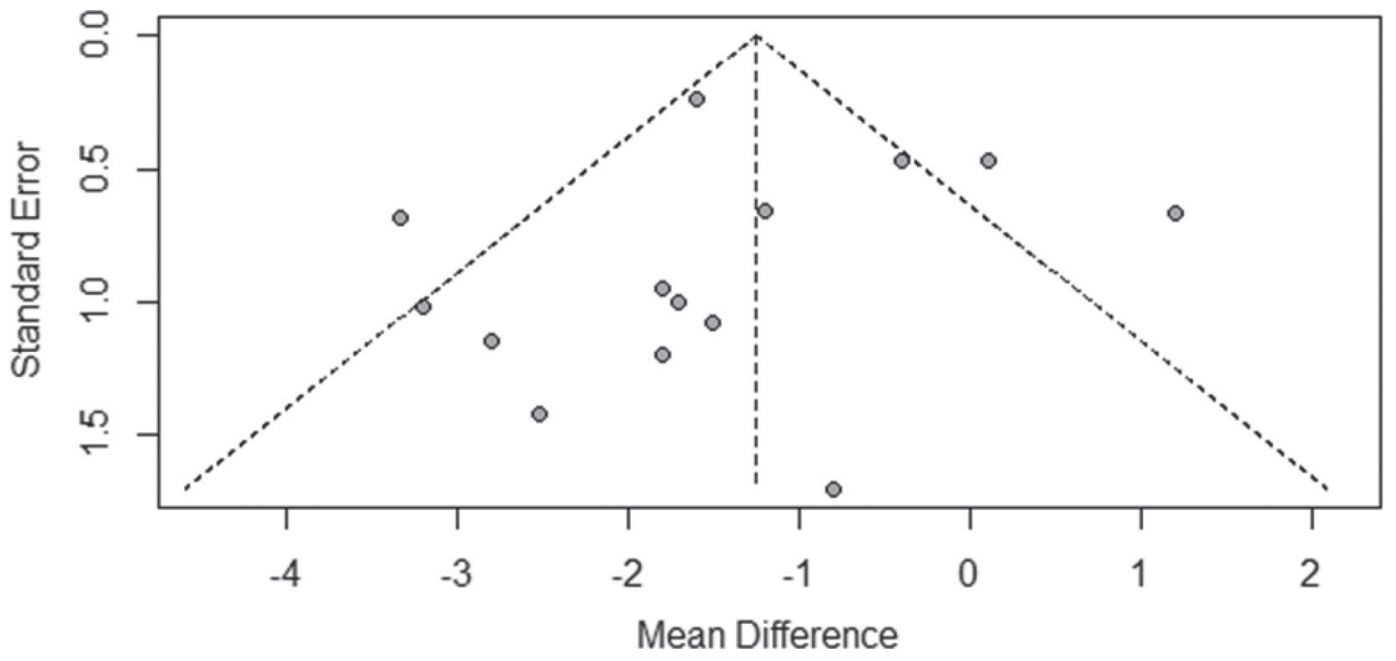

Figure 1. Funnel plot for the effect of perennial ryegrass-white clover swards on milk yield per cow. 
Table 1. Effect of introducing white clover into the sward on milk production per cow and per hectare for the grass-white clover database

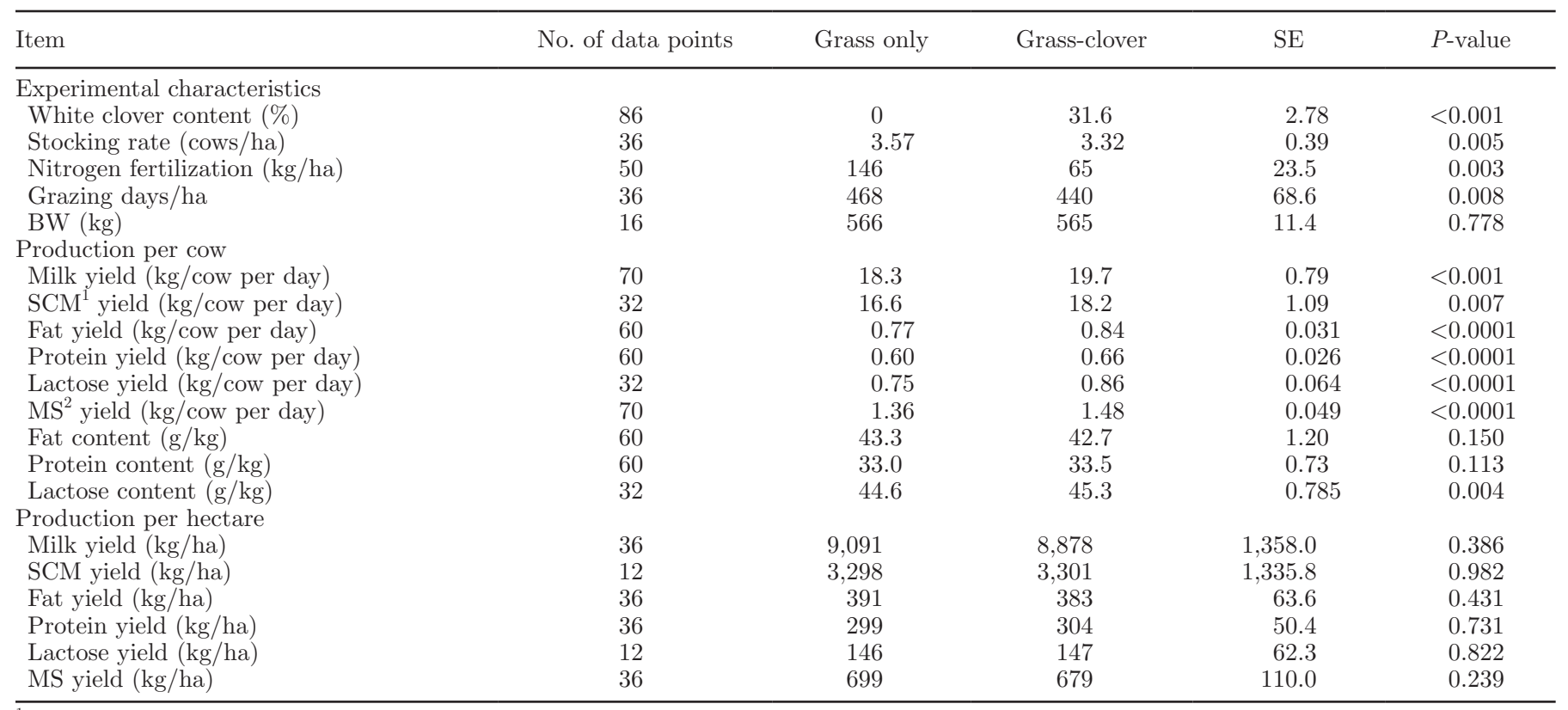

${ }^{1} \mathrm{SCM}=$ solids-corrected milk.

${ }^{2} \mathrm{MS}=$ milk solids $(\mathrm{kg}$ of fat + protein).

$=104 \mathrm{~d}, \mathrm{~N}$ application $=105 \mathrm{~kg} / \mathrm{ha}, \mathrm{WC}$ content $=$ $16.2 \%$, daily milk yield $/ \mathrm{cow}=19.0 \mathrm{~kg}$, and milk yield/ ha $=8,984 \mathrm{~kg}$. The average effect of introducing WC into a PRG sward on milk production per cow and per hectare for the GWC database is outlined in Table 1. Perennial ryegrass-WC treatments had a lower stocking rate (cows/ha) and lower rates of $\mathrm{N}$ fertilizer application $(\mathrm{kg} / \mathrm{ha})$ compared with GO treatments (3.57 cows/ha and $146 \mathrm{~kg}$ of N/ha compared with 3.32 cows/ ha and $65 \mathrm{~kg}$ of N/ha for the GO and GC treatments, respectively).

Within the GWC database, mean daily milk and MS yield per cow and $\mathrm{Gd} /$ ha for the GO treatments were $18.3 \mathrm{~kg}, 1.36 \mathrm{~kg}$, and $468 \mathrm{~d}$, respectively. When WC was introduced, mean sward WC content was $31.6 \%$, GD/ha was $440 \mathrm{~d}$, and mean daily milk and MS yields per cow were increased $(P<0.001)$ by 1.4 and $0.12 \mathrm{~kg}$, respectively. However, milk and MS yields per hectare were unaffected when cows grazed GC swards compared with GO swards, although there was a numerical reduction of 213 and $20 \mathrm{~kg}$, respectively. Introducing WC into the sward resulted in a significant increase $(P$ $<0.001)$ per cow for daily milk yield $(+7.6 \%)$ as well as fat $(+9.1 \%)$, protein $(+10.0 \%)$, MS $(+8.8 \%)$, and lactose $(+14.7 \%)$ yields. Similarly, there was a significant increase per cow at the $P<0.01$ level for daily SCM $(+9.6 \%)$. The effect of introducing WC into the sward was not consistent for fat, protein, and lactose contents, as milk fat and protein contents were unaf- fected by sward WC content $(P>0.1)$, whereas milk lactose content was increased by $1.5 \%(P<0.05)$.

The results of this meta-analysis illustrate the positive effect of sward WC inclusion on milk production per cow in grazing dairy systems but also shows the interesting interaction between sward WC inclusion and milk production per hectare. Numerous studies and reviews have reported increased milk production per cow when cows grazed GC swards compared with GO swards (Harris et al., 1997a; Woodfield and Clark, 2009; Lüscher et al., 2014). In this study, daily milk and MS yields per cow were 7.6 and $8.8 \%$ greater, respectively, for cows that grazed GC swards compared with GO swards. This is similar to Riberio-Filho et al. (2003) and Egan (2015), who reported that WC inclusion in PRG swards increased milk production by 1.0 to 1.8 $\mathrm{kg} / \mathrm{cow}$ per day when cows grazed GC swards compared with GO swards. This increase in milk production per cow was reliable when grazing GC swards, as $86 \%$ of the experiments within the GWC database reported an increase in milk production when cows grazed GC swards. This is illustrated in Figure 2, which shows the relationship between milk production per cow from cows grazing GO and GC swards, as the majority of the data points are above the $\mathrm{x}=\mathrm{y}$ line. However, in $14 \%$ of the experiments, there was no effect or a reduction in milk production per cow when cows grazed GC swards compared with GO swards. This is illustrated in Figure 3, which shows the variable response to sward 
WC inclusion within experiments in the GWC database. Milk fat and protein contents were unaffected by WC inclusion $(P>0.1)$. This is similar to EnriquezHidalgo et al. (2014) but in contrast to Woodfield and Clark (2009), who stated that WC inclusion tended to decrease milk fat content and increase milk protein content. The lack of an effect of WC on milk production per cow has also been reported previously (Ledgard et al., 1998; Humphreys et al., 2009; Enriquez-Hidalgo et al., 2014) and may be related to sward WC content. Andrews et al. (2007) stated that a sward WC content of $>20 \%$ is required to see an animal production effect, although within the GWC database, experiments that saw an increase in milk production per cow had a mean sward WC content of $35 \%$, whereas experiments that saw a decrease in milk production per cow had a mean sward WC content of $29 \%$.

When productivity was measured on a per-hectare basis, in the GWC database, milk and MS yields were not reduced, although stocking rate and $\mathrm{N}$ fertilizer application rate were reduced by 0.25 cows/ha and 81 $\mathrm{kg} / \mathrm{ha}$, respectively, for cows that grazed GC swards compared with GO swards. Within grazing systems, stocking rate, milk yield per cow, and milk yield per hectare are closely linked (McCarthy et al., 2011). Generally, as stocking rate increases milk yield per cow decreases and milk yield per hectare increases (Mac- donald et al., 2008), and vice versa. The increase in daily milk yield per cow for cows grazing on GC swards was partly attributable to the reduction in stocking rate and partly attributable to the presence of $\mathrm{WC}$ in the sward. Using the stocking rate effect prediction equations of McCarthy et al. (2011), it was calculated that $30 \%$ of the increase in milk yield per cow was attributable to the reduction in stocking rate and $70 \%$ was attributable to the presence of $\mathrm{WC}$ in the sward. However, despite the decrease in stocking rate with GC swards, milk yield per hectare was not significantly reduced. This is in contrast with previous research, which showed that generally, as stocking rate decreases, milk yield per hectare also decreases due to the reduction in Gd/ha (Macdonald et al., 2008; McCarthy et al., 2011). As evidenced from this study, grazing experiments that have compared GO and GC swards have reduced stocking rates $(-7.5 \%)$ and $\mathrm{N}$ fertilizer application rates $(-55 \%)$ on the GC swards as a routine management practice but did not have lower levels of milk production per hectare. Ryan (1989) reported that a GC system had a reduction in carrying capacity in the region of 20 to $25 \%$ and produced $84 \%$ of the milk per hectare compared with a PRG N-based system. Similarly, Humphreys et al. (2012) reported that GC systems had stocking densities, milk, and total sales that were $90 \%$ of those of GO production systems and

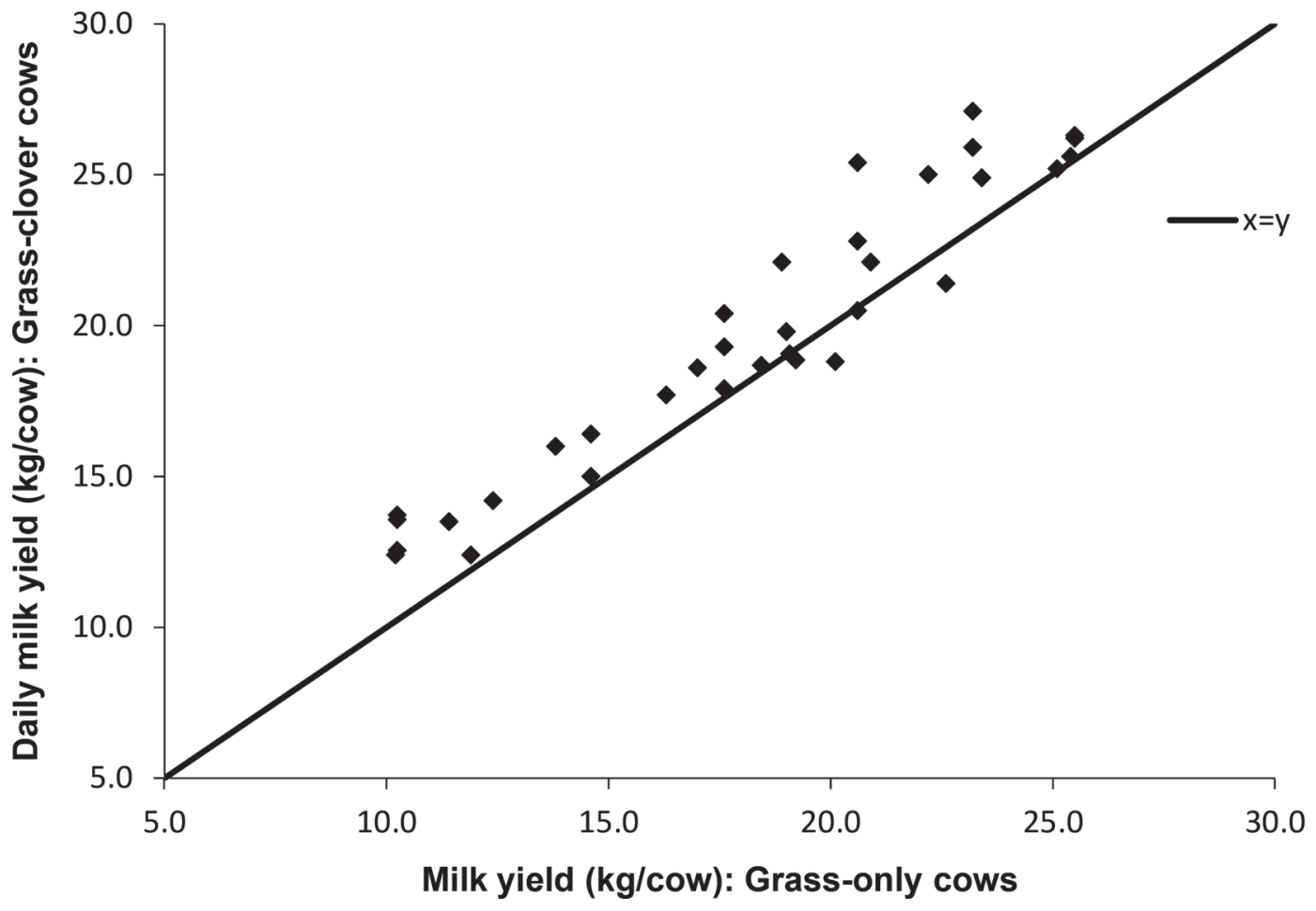

Figure 2. Relationship between perennial ryegrass-only and perennial ryegrass-white clover swards on daily milk yield per cow in the grasswhite clover database. 
that the GC systems had greater profitability than GO systems in scenarios in which high $\mathrm{N}$ fertilizer prices were combined with low or intermediate milk prices. The results of this meta-analysis highlight the potential of GC production systems to achieve levels of milk production per hectare similar to those of GO
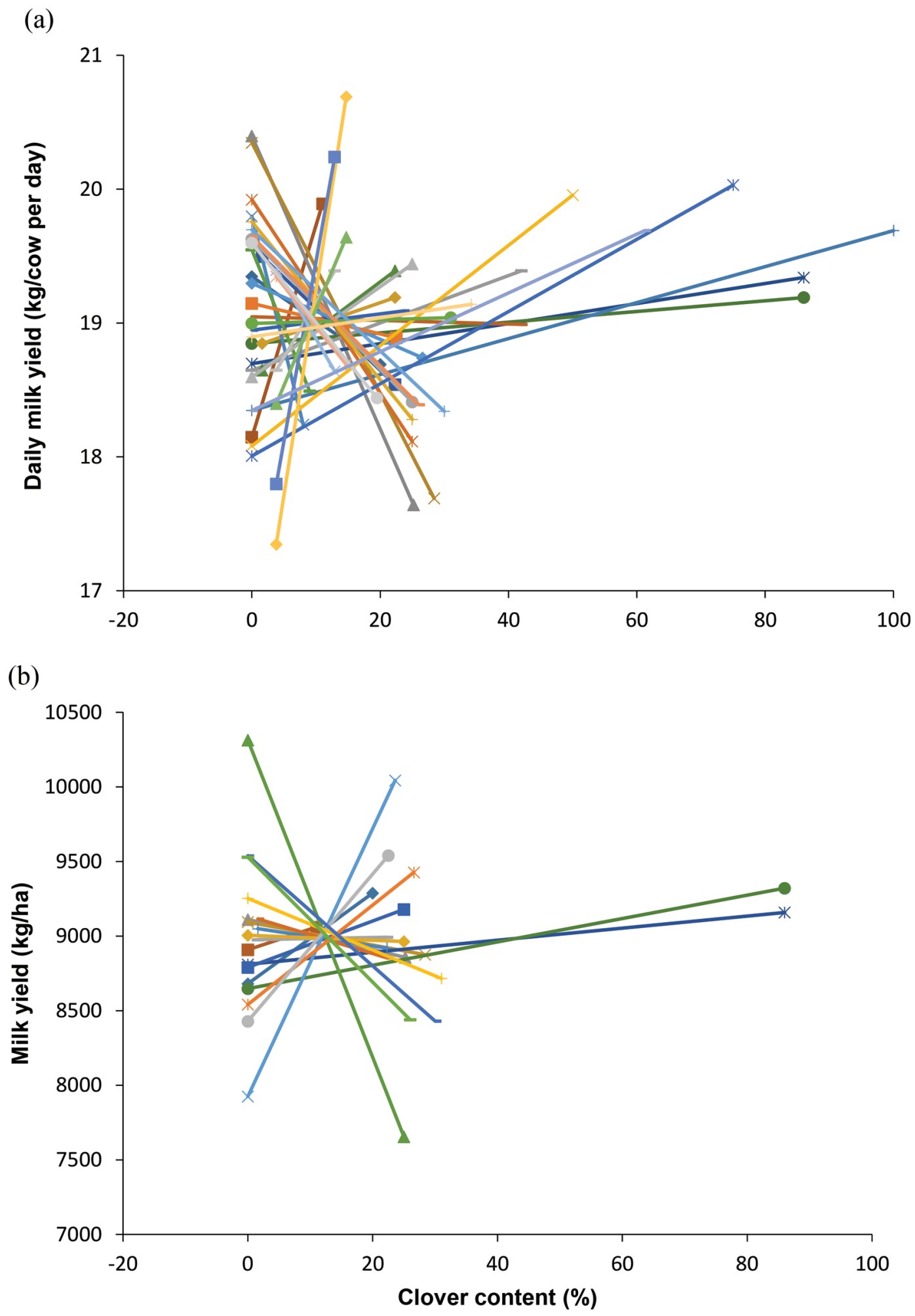

Figure 3. Visual representation of the response of (a) milk yield per cow per day and (b) milk yield per hectare to white clover inclusion in a perennial ryegrass sward within experiment for the grass-white clover database. Color version available online. 
systems but with reduced $\mathrm{N}$ fertilizer inputs, which can be beneficial from both an environmental and economic point of view, particularly in the scenario of a low milk price and a high $\mathrm{N}$ fertilizer price (Ledgard et al., 2009; Humphreys et al., 2012).

In this study, when sward nutritive data from GO and GC swards were analyzed, there was no difference in $\mathrm{OM}$ digestibility, but $\mathrm{CP}$ was greater and $\mathrm{NDF}$ and ADF were reduced on GC swards (Table 2). The increase in milk production per cow on GC swards is generally attributed to an increase in DMI (Harris et al., 1997a; Riberio-Filho et al., 2003). The chemical and physical attributes of GC swards that have been illustrated in this study (i.e., greater $\mathrm{CP}$ and reduced NDF compared with GO swards) give rise to a higher voluntary DMI and a higher net supply of both energy and protein and a subsequent increase in milk production (Ulyatt, 1980). Although WC has a greater OM digestibility than PRG (Ulyatt et al., 1988), within this study GC swards did not have a greater OM digestibility than GO swards, which has been reported previously (Egan, 2015). However, there is also evidence to suggest that the positive effects of GC swards are associative and are attributable to a faster digestion of the soluble fraction of legumes, a higher rate of particle breakdown, and a higher passage rate through the rumen (Dewhurst et al., 2003; Niderkorn and Baumont, 2009).

\section{Effect of Sward WC Content on Milk Production}

The mean effect of GC swards on milk production per cow and per hectare for the WCO database is outlined in Table 3. Within the WCO database, the mean experimental characteristics and milk production per cow and per hectare were as follows: number of cows $=$ 43 , stocking rate $=2.67$ cows $/$ ha, experiment length $=$ $126 \mathrm{~d}, \mathrm{~N}$ application $=87 \mathrm{~kg} / \mathrm{ha}, \mathrm{WC}$ content $=21.9 \%$, daily milk yield $/ \mathrm{cow}=19.4 \mathrm{~kg}$, and milk yield $/ \mathrm{ha}=$ $10,458 \mathrm{~kg}$.

The equations that accounted for the greatest proportion of variation in predicted milk production per cow and per hectare according to sward WC content in the WCO database are described in Table 4 and Figure 2. The residual standard error is low at 1.18 for daily milk yield, indicating a good precision of the predictive equations. Linear equations accounted for the greatest proportion of the variance for daily SCM and lactose yields and fat and lactose contents per cow, and quadratic equations accounted for the greatest proportion of variation for daily milk, fat, protein, and MS yields and lactose content per cow. For milk production per hectare variables, linear equations accounted for the greatest proportion of the variance for all variables, as $\mathrm{Gd} /$ ha had a significant effect on all per-hectare variables with the exception of lactose yield per hectare. On the basis of the predictive equations for the per-cow variables in Table 4, a 10\% sward WC content increase (between a sward WC content of 0 and $60 \%$ ) resulted in a significant $(P<0.05)$ mean proportional increase per cow of $+2.87 \%$ for daily milk yield, $+4.41 \%$ for daily fat yield, $+4.21 \%$ for daily protein yield, and $+4.34 \%$ for daily MS yield. Although there were also numerical increases in daily SCM $(+1.72 \%)$ and lactose $(+1.39 \%)$ yields, neither of these was statistically significantly. When fat, protein, and lactose contents were examined on a per-cow basis, the only significant increase was in protein content. On the basis of the predictive equations for the per-hectare variables, a $10 \%$ sward WC content increase increased milk, fat, protein, lactose, and MS yields per hectare by $2.8,15.4,13.2,26.9$, and $10.0 \%$, respectively. In this analysis, experiment length was greater than $150 \mathrm{~d}, \mathrm{Gd} /$ ha was kept constant as WC content increased (stocking rate was kept constant at 2.50 cows / ha for every $10 \%$ increase in WC content), and sward WC content was between 0 and $60 \%$. The range of $\mathrm{WC}$ content was restricted to 0 to $60 \%$, as no data for swards with WC content greater than $60 \%$ were available in the data set. Figure 4 shows the difference in response to changing sward WC content on a yield per cow and yield per hectare basis where Gd/ ha is kept constant.

The equations that accounted for the greatest proportion of variation in predicted daily milk and MS yields per cow and milk and MS yields per hectare according to sward WC content, stocking rate, and $\mathrm{N}$ fertilizer are described in Table 5. On the basis of the predictive equations, daily milk yield per cow was not affected by WC content, linearly increased with $\mathrm{N}$ fertilizer $(0.012$

Table 2. Effect of introducing white clover into the sward on nutritive value in the grass-white clover database

\begin{tabular}{lcccrc}
\hline Item & $\begin{array}{c}\text { No. of data } \\
\text { points }\end{array}$ & Grass only & Grass-clover & SE & $P$-value \\
\hline OM digestibility $(\mathrm{g} / \mathrm{kg})$ & 34 & 751 & 760 & 13.2 & 0.282 \\
CP (g/kg) & 30 & 184 & 203 & 7.9 & 0.014 \\
NDF $(\mathrm{g} / \mathrm{kg})$ & 30 & 515 & 450 & 19.7 & 0.001 \\
ADF $(\mathrm{g} / \mathrm{kg})$ & 20 & 269 & 257 & 8.7 & 0.012 \\
\hline
\end{tabular}


Table 3. Mean production data for the white clover-only database experimental data

\begin{tabular}{|c|c|c|c|c|c|}
\hline Item & $\begin{array}{c}\text { No. of } \\
\text { data points }\end{array}$ & Mean & $\mathrm{SD}$ & Minimum & Maximum \\
\hline \multicolumn{6}{|l|}{ Experimental characteristics } \\
\hline No. of cows & 131 & 43 & 18.3 & 8 & 81 \\
\hline Clover proportion (\%) & 131 & 21.9 & 15.46 & 0.9 & 100 \\
\hline Stocking rate (cows/ha) & 66 & 2.67 & 1.1280 & 0.67 & 6.4 \\
\hline Nitrogen fertilization $(\mathrm{kg} / \mathrm{ha})$ & 76 & 87 & 71.2 & 0 & 353 \\
\hline Experimental length (d) & 131 & 126 & 107.2 & 8 & 365 \\
\hline Grazing days/ha (d) & 66 & 539 & 272.9 & 16 & 1,190 \\
\hline $\mathrm{BW}(\mathrm{kg} / \mathrm{cow})$ & 23 & 562 & 40.8 & 501 & 612 \\
\hline \multicolumn{6}{|l|}{ Production per cow } \\
\hline Milk yield (kg/cow per day) & 131 & 19.4 & 3.88 & 10.5 & 27.1 \\
\hline $\mathrm{SCM}^{1}$ vield ( $\mathrm{kg} /$ cow per dav) & 60 & 17.3 & 4.46 & 11.2 & 25.6 \\
\hline Fat yield (kg/cow per day) & 104 & 0.79 & 0.172 & 0.49 & 1.16 \\
\hline Protein yield (kg/cow per day) & 104 & 0.62 & 0.128 & 0.41 & 0.89 \\
\hline Lactose yield ( $\mathrm{kg} / \mathrm{cow}$ per day) & 60 & 0.84 & 0.244 & 0.52 & 1.28 \\
\hline $\mathrm{MS}^{2}$ yield $(\mathrm{kg} / \mathrm{cow}$ per day) & 124 & 1.41 & 0.270 & 0.91 & 2.02 \\
\hline Fat content $(\mathrm{g} / \mathrm{kg})$ & 104 & 40.8 & 6.34 & 24.7 & 55.6 \\
\hline Protein content $(\mathrm{g} / \mathrm{kg})$ & 104 & 32.2 & 4.41 & 21.0 & 43.7 \\
\hline Lactose content $(\mathrm{g} / \mathrm{kg})$ & 60 & 43.0 & 6.44 & 27.0 & 50.0 \\
\hline \multicolumn{6}{|l|}{ Production per hectare } \\
\hline Milk yield $(\mathrm{kg} / \mathrm{ha})$ & 66 & 10,458 & $5,132.9$ & 310 & 22,133 \\
\hline Fat yield (kg/ha) & 44 & 348 & 249.2 & 14 & 1.094 \\
\hline Protein yield (kg/ha) & 44 & 279 & 194.1 & 10 & 826 \\
\hline Lactose vield $(\mathrm{kg} / \mathrm{ha})$ & 15 & 269 & 141.4 & 40 & 449 \\
\hline MS yield ( $\mathrm{kg} / \mathrm{ha})$ & 60 & 730 & 415.7 & 24 & 1,822 \\
\hline
\end{tabular}

${ }^{1} \mathrm{SCM}=$ solids-corrected milk.

${ }^{2} \mathrm{MS}=$ milk solids $(\mathrm{kg}$ of fat + protein $)$.

$\mathrm{kg}$ of milk/ $\mathrm{kg}$ of $\mathrm{N})$, and linearly decreased with stocking rate $(-3.3 \mathrm{~kg}$ of milk/unit change in stocking rate). Milk yield per hectare increased linearly by $13.7 \mathrm{~kg}$ of milk/unit change in $\mathrm{Gd} / \mathrm{ha}$ and $5.4 \mathrm{~kg}$ of milk/ $\mathrm{kg}$ of $\mathrm{N}$ $(P<0.01)$, whereas WC content did not affect milk yield per hectare.

Perennial ryegrass and $\mathrm{WC}$ are the 2 most common grass and legume species grown together, due mainly to their contrasting relationship with $\mathrm{N}$ and differences in seasonal growth patterns and nutritive value (Chapman et al., 1996; Phelan, 2013). A balance of both $\mathrm{PRG}$ and $\mathrm{WC}$ is required to increase milk production without compromising annual pasture DM production. Andrews et al. (2007) stated that a sward WC content of $>20 \%$ is required to see an animal production effect; however, the optimum level of WC for milk and pasture DM production is not well described in the literature. Several studies have reported increased daily milk yield per cow with increasing sward WC contents (Harris et al., 1997a; Lee et al., 2004). Harris et al. (1997a) compared milk production from mixed GC swards with WC contents of $0,25,50$, and $75 \%$ and reported that milk and MS yields increased with increasing sward WC content up to $50 \%$ but that increasing WC content above $50 \%$ had no effect on milk or MS yields. In this study, within the WCO database, where milk production from GC swards with differing WC contents were compared, there was a quadratic response $(P=0.038)$ for milk and MS yields per cow as sward WC increased (Table 4; Figure 4). Above a sward WC content of $60 \%$ for milk and MS yields, production per cow begins to decline. This may be due to the lack of data above sward WC contents of $60 \%$; however, Niderkorn and Baumont (2009) hypothesized that when the legume proportion in the diet is too high (i.e., $>50 \%$ ), the benefit of legumes may decrease as excess $\mathrm{N}$ results in an intense production of urea and an increase in excreted N. Also, the risk of bloat is increased when sward WC contents are too high (Clarke and Reid, 1974). When $\mathrm{Gd} /$ ha was included (and kept constant at $650 \mathrm{~d}$ ) in the prediction equations for the per-hectare variables, milk and MS yields per hectare increased linearly as sward WC content increased (Figure 4) up to $60 \%$ in the WCO database. Milk solids yield per hectare increased as milk fat and protein yields per cow increased as sward WC content increased. Grazing days per hectare had a significant effect on all per-hectare variables with the exception of lactose yield per hectare, as expected, and was included in the model to allow a more precise prediction of the effect of WC content on production per hectare, as the study effect did not account for all of the variation in $\mathrm{Gd} /$ ha between experiments. This is in contrast to the GWC database, where milk yield per hectare was not significantly affected but was reduced 
DAIRY INDUSTRY TODAY

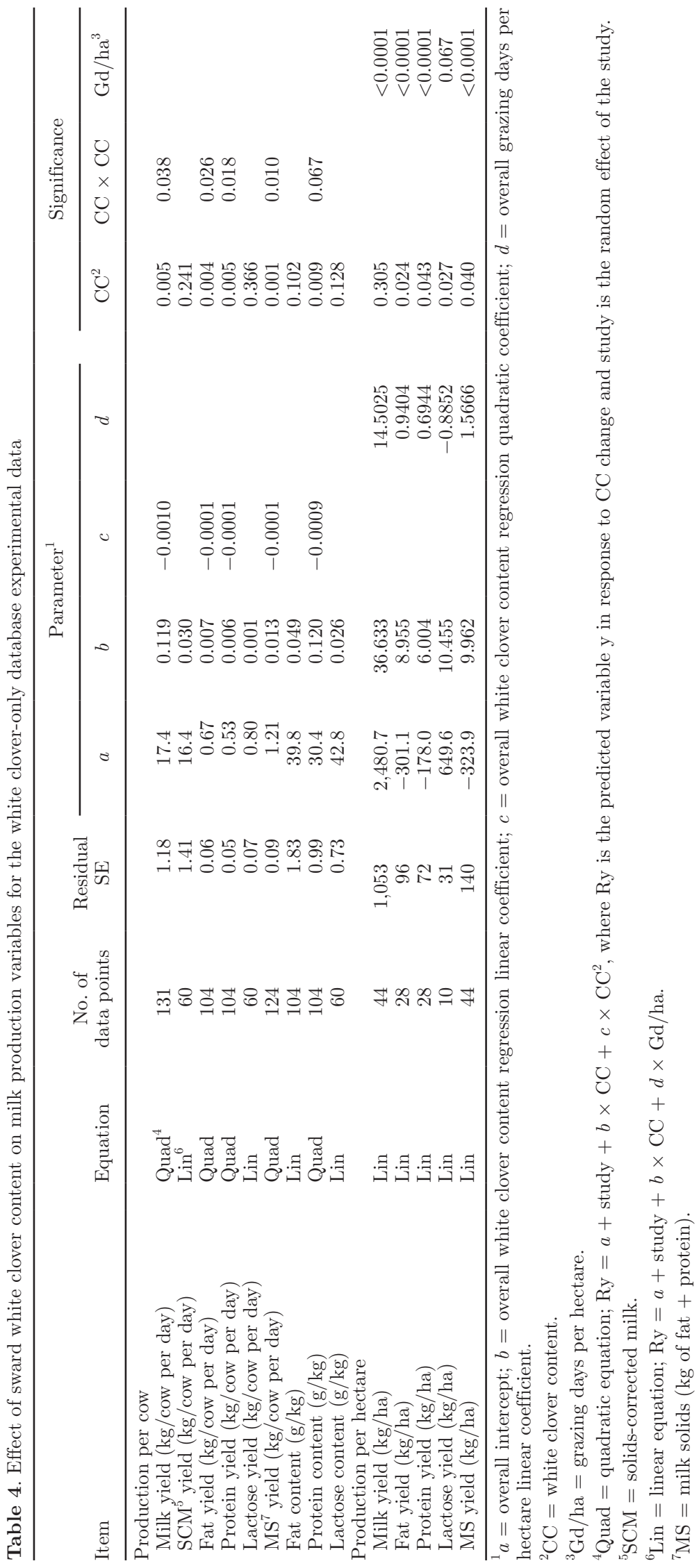




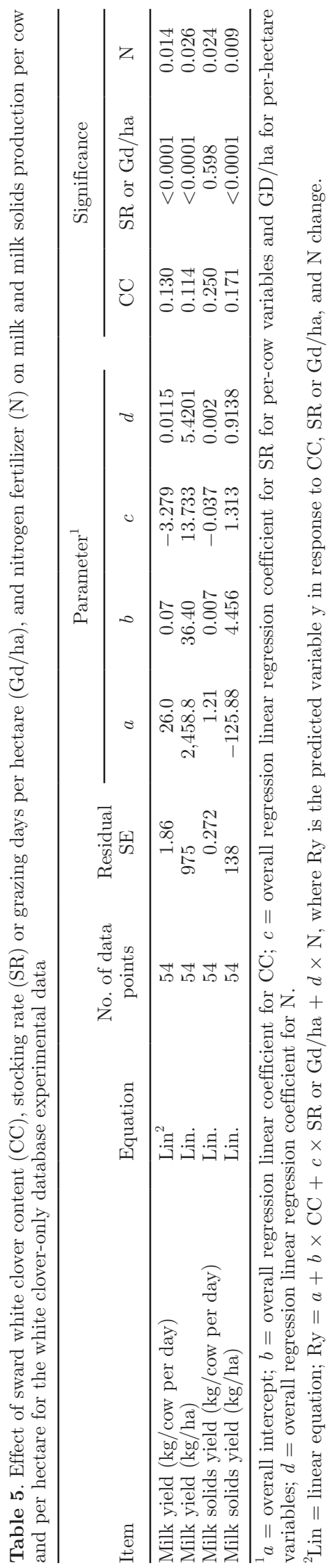

numerically when WC was included in a sward as stocking rate and $\mathrm{N}$ fertilizer application were reduced and is a reflection of the altered grazing management practices that have traditionally been associated with GC swards.

A balance between the optimum sward WC content for milk production and pasture production must be achieved to optimize both animal and pasture performance. However, within a sward the percentage of PRG and $\mathrm{WC}$ will oscillate in time and space and the overall level of control of pasture composition will be lower than what can be achieved with PRG monocultures (Chapman et al., 2016). Therefore, it can be difficult to maintain optimum levels of WC in the sward because climatic factors (drought), pests (insects and nematodes), poor soil fertility, and grazing management can all negatively affect sward WC content (Woodfield and Caradus, 1996). The most controllable factor that influences sward WC content is $\mathrm{N}$ fertilizer application.

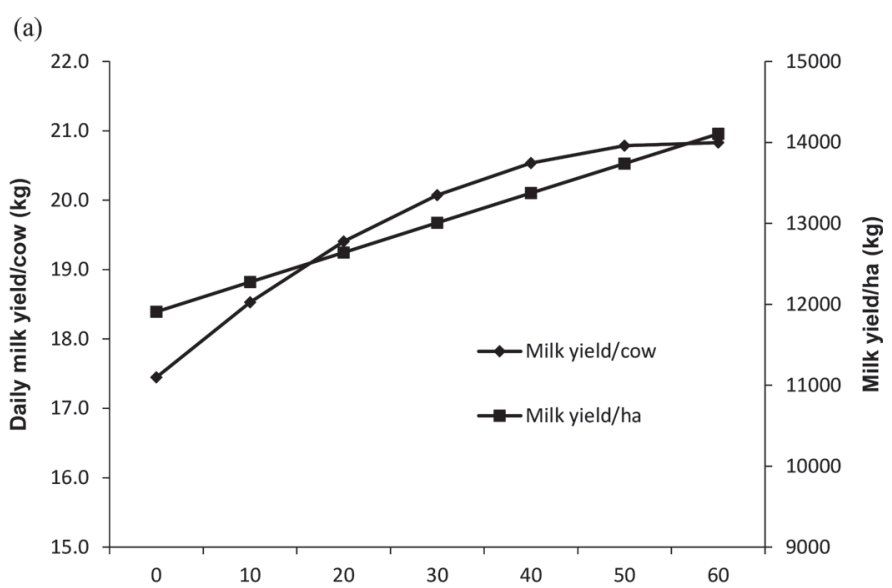

(b)

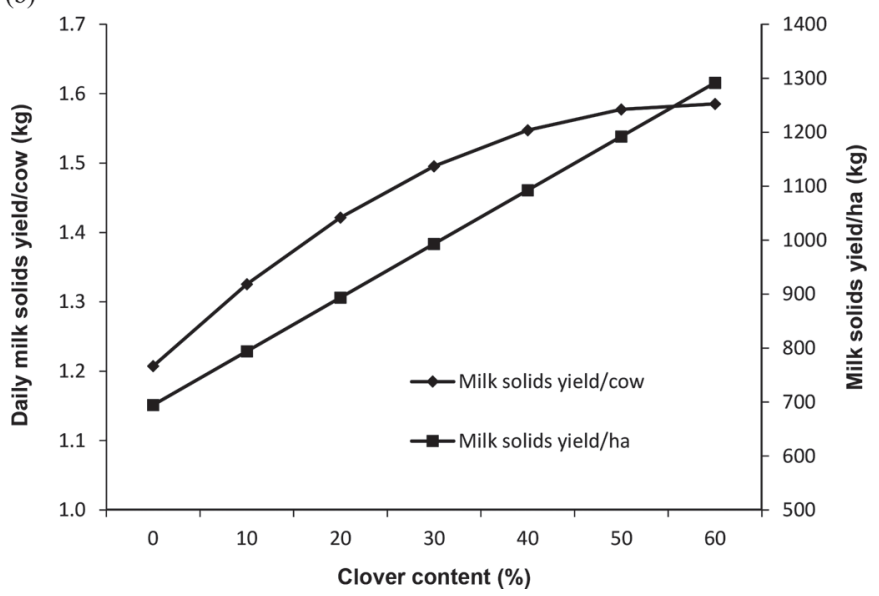

Figure 4. Effect of a change in sward white clover content on (a) daily milk production per cow and per hectare and (b) daily milk solids per cow and milk solids per hectare according to sward white clover content in the white clover-only database. 
Several studies have shown a negative relationship between $\mathrm{N}$ fertilizer and sward WC content and biological N fixation (Clark and Harris, 1996; Phelan, 2013), and within both databases where mean sward WC contents were 33.6 and $22.3 \%$ on GC swards for the GWC database and the WCO database, respectively, $\mathrm{N}$ fertilizer applications were reduced significantly compared with GO swards. Harris et al. (1997b) reported that an N fertilizer application rate of $200 \mathrm{~kg} / \mathrm{ha}$ per year may be the most suitable for pasture DM production and WC persistence. However, within grazing systems, the overall $\mathrm{N}$ inputs, whether from $\mathrm{N}$ fertilizer or biologically fixed by WC, affect the level of nutrients that can potentially be lost to groundwater. Therefore, reduced $\mathrm{N}$ fertilizer use does not necessarily lead to improved environmental conditions from a nutrient leaching perspective (Ledgard et al., 2009). However, at similar total $\mathrm{N}$ inputs, GC swards have lower greenhouse gas emissions than N-fertilized GO swards (Ledgard et al., 2009; Li et al., 2011; Yan et al., 2013). Therefore, in the European Union, where $\mathrm{N}$ fertilizer application is already limited by the nitrates directive, the use of WC should be increased to potentially further reduce the use of $\mathrm{N}$ fertilizer and to increase the sustainability of pasture-based ruminant production systems (Peyraud et al., 2009).

Within pasture-based dairy production systems, increasing milk production should first be achieved by increasing pasture DM production and by increasing stocking rate to match and utilize the extra pasture produced rather than by the importation of increased supplement into the system (Dillon et al., 2008; Ramsbottom et al., 2015). In the context of increased demand for dairy products, there may be potential to increase the productivity of pasture-based dairy systems by combining increased $\mathrm{N}$ fertilizer use with WC swards to increase stocking rate and carrying capacity while also retaining the benefit of WC inclusion, in terms of increased animal performance (i.e., increased milk production per cow), to increase milk production per hectare. However, the increased use of $\mathrm{N}$ fertilizer in conjunction with WC would need to be monitored closely from an environmental perspective (in particular $\mathrm{N}$ leaching), as total $\mathrm{N}$ inputs into the systems could be increased. Higher stocking rates or a faster grazing rotation - that is, maintaining a pre-grazing yield $(>4 \mathrm{~cm}$ ) of approximately 1,400 to $1,600 \mathrm{~kg}$ of DM/ha (i.e., a 21-d rotation; Wims et al., 2014) and defoliating swards at the correct PRG leaf stage (2 to 3 ) depending on the time of year (Turner et al., 2006) - can offset the adverse effects of $\mathrm{N}$ fertilizer on $\mathrm{WC}$ by utilizing the additional pasture produced and reducing competition for light (Woodfield and Caradus, 1996).

\section{CONCLUSIONS}

The results of this meta-analysis highlight the potential of GC production systems to increase milk production per cow and achieve overall levels of milk production similar to those of a GO systems but with reduced fertilizer $\mathrm{N}$ inputs, which is beneficial from both an economic and environmental point of view. In the context of increased demand for dairy products, there may also be potential to increase the productivity of GC systems by increasing fertilizer $\mathrm{N}$ use to increase stocking rate and carrying capacity while also retaining the benefit of $\mathrm{WC}$ inclusion on milk production per cow.

\section{ACKNOWLEDGMENTS}

The authors thank Jim Grant (Teagasc) for his assistance with the statistical analysis of the data. The authors acknowledge the financial support of the Teagasc Walsh Fellowship and the Irish Dairy Levy.

\section{REFERENCES}

Andrews, M., D. Scholfield, M. T. Abberton, B. A. McKenzie, S. Hodge, and J. A. Raven. 2007. Use of white clover as an alternative to nitrogen fertilizer for dairy pastures in nitrate vulnerable zones in the UK: Productivity, environmental impact and economic considerations. Ann. Appl. Biol. 151:11-23.

Bryant, A. M., K. A. Macdonald, and D. G. Clayton. 1981. Effects of nitrogen fertilizer on production of milk solids from grazed pasture. Proc. N. Z. Grassl. Assoc. 43:58-63.

Chapman, D. F., J. M. Lee, L. Rossi, G. R. Edwards, J. B. Pinxterhuis, and E. M. K. Minniee. 2016. White clover: The forgotten component of high producing pastures? Anim. Prod. Sci. https:// doi.org/10.1071/AN16453.

Chapman, D. F., A. J. Parsons, and S. Schwinning. 1996. Management of clover in grazed pastures: Expectations, limitations and opportunities. Pages 55-64 in White Clover: New Zealand's Competitive Edge. Special Publication No.11/Grassland Research and Practice Series No.6. D. R. Woodfield, ed. Agronomy Society of New Zealand, Palmerston North, New Zealand.

Clark, D. A., and S. L. Harris. 1996. White clover or nitrogen fertilizer for dairying? Agronomy Society of New Zealand Special Publication No. 11/Grassland Research and Practice Series No. 6:107-114.

Clarke, R. T. J., and C. S. W. Reid. 1974. Foamy bloat of cattle. A review. J. Dairy Sci. 57:753-785.

Cosgrove, G. P., J. L. Burke, A. F. Death, G. A. Lane, K. Fraser, D. Pacheco, and A. J. Parsons. 2006. Clover-rich diets and production, behaviour and nutrient use by cows in late lactation. Proc. N. Z. Soc. Anim. Prod. 66:42-49.

Delaby, L., J. Pavie, B. McCarthy, E. A. Comero, and J. L. Peyraud. 2016. Les légumineuses fourragères, indispensables à l'élevage de demain. Fourrages (Versailles) 226:77-86.

Dewhurst, R. J., W. J. Fisher, J. K. S. Tweed, and R. J. Wilkins. 2003. Comparison of grass and legume silages for milk production. 1. Production responses with different levels of concentrate. J. Dairy Sci. 86:2598-2611.

Dillon, P., T. Hennessy, L. Shalloo, F. Thorne, and B. Horan. 2008. Future outlook for the Irish dairy industry: A study of international competitiveness, influence of international trade reform and requirement for change. Int. J. Dairy Technol. 61:16-29. 
Egan, M. 2015. Strategies to increase white clover in intensive dairy production systems. PhD Diss. National University of Ireland, Dublin, Ireland.

Egan, M. J., M. B. Lynch, and D. Hennessy. 2015. Herbage and milk production from a grass-only sward and grass-white clover swards in an intensive grass-based system. Pages 93-95 in Grassland Science in Europe, Vol. 20: Grassland and Forages in High Output Dairy Farming Systems. A. van den Pol-van Dasselaar, H. F. M. Aarts, A. De Vliegher, A. Elgersma, D. Reheul, J. A. Reijneveld, J. Verloop, and A. Hopkins, ed. Wageningen Academic Publishers, Wageningen, the Netherlands.

Enriquez-Hidalgo, D., T. Gilliland, M. H. Deighton, M. O'Donovan, and D. Hennessy. 2014. Milk production and enteric methane emissions by dairy cows grazing fertilized perennial ryegrass pasture with or without inclusion of white clover. J. Dairy Sci. 97:1400-1412.

Glass, G. V. 1976. Primary, secondary, and meta-analysis of research. Educ. Res. 5:3-8

Godfray, H. C., J. R. Beddington, I. R. Crute, L. Haddad, D. Lawrence, J. F. Muir, J. Pretty, S. Robinson, S. M. Thomas, and C. Toulmin. 2010. Food security: The challenge of feeding 9 billion people. Science 327:812-818.

Harris, S. L., D. A. Clark, M. J. Auldist, C. D. Waugh, and P. G. Laboyrie. 1997a. Optimum white clover content for dairy pastures. Proc. N. Z. Grassl. Assoc. 59:29-33.

Harris, S. L., D. A. Clark, C. D. Waugh, and F. H. Clarkson. 1997b. Nitrogen fertilizer effects on white clover in dairy pastures. Pages 119-124 in White Clover: New Zealand's Competitive Edge. Special Publication No.11/Grassland Research and Practice Series No.6. D. R. Woodfield, ed. Agronomy Society of New Zealand, Palmerston North, New Zealand

Humphreys, J., I. A. Casey, and A. S. Laidlaw. 2009. Comparison of milk production from clover-based and fertilizer-N-based grassland on a clay-loam soil under moist temperate climatic conditions. Ir. J. Agric. Food Res. 48:189-207.

Humphreys, J., E. Mihailescu, and I. A. Casey. 2012. An economic comparison of systems of dairy production based on N-fertilized grass and grass-white clover in grassland in a moist maritime environment. Grass Forage Sci. 67:519-525.

Lean, I. J., A. R. Rabiee, T. F. Duffield, and I. R. Dohoo. 2009. Invited review: Use of meta-analysis in animal health and reproduction: Methods and applications. J. Dairy Sci. 92:3545-3565.

Ledgard, S., R. Schills, J. Eriksen, and J. Luo. 2009. Environmental impacts of grazed clover/grass pastures. Ir. J. Agric. Food Res. 48:209-226.

Ledgard, S. F., J. R. Crush, and J. W. Penno. 1998. Environmental impacts of different nitrogen inputs on dairy farms and implications for the Resource Management Act of New Zealand. Environ. Prog. 102:515-519.

Lee, J. M., S. L. Woodward, G. C. Waghorn, and D. A. Clark. 2004. Methane emissions by dairy cows fed increasing proportions of white clover (Trifolium repens) in pasture. Proc. N. Z. Grassl. Assoc. $66: 151-155$.

Li, D., G. Lanigan, and J. Humphreys. 2011. Measured and simulated nitrous oxide emissions from ryegrass- and ryegrass/white clover-based grasslands in a moist temperate climate. PLoS One $6: \mathrm{e} 26176$.

Lüscher, A., I. Mueller-Harvey, J. F. Soussana, R. M. Rees, and J. L. Peyraud. 2014. Potential of legume-based grassland-livestock systems in Europe: A review. Grass Forage Sci. 69:206-228.

Macdonald, K. A., J. W. Penno, J. A. S. Lancaster, and J. R. Roche. 2008. Effect of stocking rate on pasture production, milk produc- tion and reproduction of dairy cows in pasture-based systems. J. Dairy Sci. 91:2151-2163.

McCarthy, B., L. Delaby, K. M. Pierce, F. Journot, and B. Horan. 2011. Meta-analysis of the impact of stocking rate on the productivity of pasture-based milk production systems. Animal 5:784-794.

Niderkorn, V., and R. Baumont. 2009. Associative effects between forages on feed intake and digestion in ruminants. Animal 3:951-960.

Peyraud, J. L., A. Le Gall, and A. Lüscher. 2009. Potential food production from forage legume-based-systems in Europe: An overview. Ir. J. Agric. Food Res. 48:115-135.

Phelan, P. 2013. Aspects of grazing management to improve productivity and persistence of white clover in Irish grassland. PhD Diss. Waterford Institute of Technology, Waterford, Ireland.

Ramsbottom, G., B. Horan, D. P. Berry, and J. R. Roche. 2015. Factors associated with the financial performance of spring-calving, pasture-based dairy farms. J. Dairy Sci. 98:3526-3540.

Riberio Filho, H. M. N., R. Delagarde, and J. L. Peyraud. 2003. Inclusion of white clover in strip-grazed perennial ryegrass swards: Herbage intake and milk yield of dairy cows at different ages of sward regrowth. Anim. Sci. 77:499-510.

Ryan, M. 1989. Development of a legume-based dairy system. Pages 159-167 in Legumes in Farming Systems. P. Plancquaert and R. Haggar, ed. Springer International Publishing, Cham, Switzerland.

Sauvant, D., P. Schmidely, J. J. Daudin, and N. R. St-Pierre. 2008 Meta-analyses of experimental data in animal nutrition. Animal $2: 1203-1214$.

Schwarzer, G., J. R. Carpenter, and G. Rücker. 2015. Meta-Analysis with R. Springer International Publishing, Cham, Switzerland.

St-Pierre, N. R. 2001. Invited review: Integrating quantitative findings from multiple studies using mixed model methodology. J. Dairy Sci. 84:741-755.

SAS Institute. 2006. Users Guide: Statistics. Version 9.1. SAS Institute Inc., Cary, NC.

Turner, L. R., D. J. Donaghy, P. A. Lane, and R. P. Rawnsley. 2006. Effect of defoliation management, based on leaf stage, on perennial ryegrass (Lolium perenne L.), prairie grass (Bromus willdenowii Kunth.) and cocksfoot (Dactylis glomerata L.) under dryland conditions. 1. Regrowth, tillering and water-soluble carbohydrate concentration. Grass Forage Sci. 61:164-174.

Ulyatt, M. J., D. Thomson, D. Beever, R. Evans, and M. Haines. 1988 The digestion of perennial ryegrass (Lolium perenne cv. Melle) and white clover (Trifolium repens cv. Blanca) by grazing cattle. Br. J. Nutr. 60:137-149.

Ulyatt, M. H. 1980. The feeding value of temperate pasture. Pages 125-141 in Grazing Animals. F. H. W. Morley, ed. Elsevier Scientific, Amsterdam, the Netherlands.

Wims, C. M., L. Delaby, T. M. Boland, and M. O'Donovan. 2014. Effect of pre-grazing herbage mass on dairy cow performance, grass dry matter production and output from perennial ryegrass (L.) pastures. Animal 8:141-151.

Woodfield, D. R., and J. R. Caradus. 1996. Factors affecting white clover persistence in New Zealand pastures. Proc. N. Z. Grassl. Assoc. 58:229-235.

Woodfield, D. R., and D. A. Clark. 2009. Do forage legumes have a role in modern dairy farming systems? Ir. J. Agric. Food Res. 48:137-147.

Yan, M.-J., J. Humphreys, and N. M. Holden. 2013. The carbon footprint of pasture-based milk production: Can white clover make a difference? J. Dairy Sci. 96:857-865. 